\title{
PSYCHOLOGICAL EFFECTS IN DEPRESSIVE PATIENTS OF THE MARIHUANA HOMOLOGUE SYNHEXYL
}

\author{
BY \\ D. A. POND \\ From the Institute of Psychiatry, Maudsley Hospital, London
}

(RECEIVED MARCH 24, 1948)

The search for drugs to combat psychiatric symptoms, especially depression, has a long history. Because of the close association, particularly in the sufferer's mind, between pain and mental anguish, the opiates have often been used for alleviating such symptoms. Hashish, likewise, for long known to produce pleasant, dreamy states, has been used at times, and a very recent example of its recommendation is for the reducing of anxiety and tension in patients with duodenal ulcer (Douthwaite, 1947).

Interest in the chemistry of hashish, or marihuana as it is usually called in America, has recently led two or three groups of workers-Todd (1945) in Cambridge, and Adams (1942) and Loewe (1944) in the United States in particular - to investigate various compounds isolated from it. They have also prepared homologues of the natural products, and of these synhexyl showed the most promise of being useful as a euphoriant. It has become available for clinical trial, and Stockings (1947) recently published a report on its favourable effects in alleviating depressive mental states in fifty patients, more than half of whom were chronic mental hospital inmates. The investigations to be reported here were on a smaller group of patients-fourteenwho were intensively studied with a view to gaining a clear picture of the effect of the drug and its value in the treatment of depression.

\section{Method of Investigation}

The patients were examined in groups of two or three at a time. Except for the earliest group of three patients, on whom subsequent dosage was standardized, and who exhibited mainly depersonalization in a setting of depression or hysteria, they were all in patients selected because of a predominant clinical picture of depression. All were voluntary patients, and able to co-operate fully in the investigation.

The examination of the effect of the drug was carried out by means of clinical study throughout the period of its effect, by simple psychological tests, to be detailed below, and by introspective reports in answer to certain standard questions. In order to sharpen the clinical impression a comparison with benzedrine was made. The total period of study of each group of patients lasted four days : a control day with clinical examination and a short rehearsal of the psychological tests given without any drug; a second day beginning with $30 \mathrm{mg}$. synhexyl at 9 a.m. ; a third with 20 mg. benzedrine at 9 a.m. ; and a fourth with $40 \mathrm{mg}$. synhexyl at 9 a.m. Tests were carried out at 9 a.m. before any drug effect had occurred, at 1.30 p.m. when the action was usually at its height, and at 3.30 p.m. when the action was wearing off. These four days were not necessarily consecutive but were usually all within one week, and the order of the giving of the drugs was always the same. In the earliest groups, tests were also made at 11.30 a.m., but these yielded no significant differences when compared with the findings at 1.30 p.m. and 3.30 p.m.

\section{The General Clinical Picture}

About two hours after the ingestion of synhexyl, there was a sudden onset of drowsiness and lightheadedness, .spontaneously described by several subjects as like the early states of intoxication by alcohol. The sensation might pass off in a few minutes, but it then recurred in waves of increasing depth and length, the maximum effect being obtained from three to five hours after taking the drug. What might be described as a "pre-intoxicated". stage occurred in most patients with the smaller dose of synhexyl. The characteristics of this period were related closely to the underlying personality, and are discussed later. In general the subjects showed an increase in apprehension and a clear subjective awareness of lack of being master of themselves, leading in some to a pleasant lackadaisical state, and in others to a more definitely unpleasant increased preoccupation with the fears and worries of their depressive condition. With larger doses the clinical picture became more uniform again, as 
the subjects passed inte a state of slight but definite impairment of consciousness which might be accompanied by very marked drowsiness. Sleep was light and accompanied by dreams. The exhibition of the drug to patients in groups showed clearly that there was an increase in suggestibility, for the symptoms of all the subjects in any one group tended to be similar to each other, but to differ from those of another group. For example, the members of one group stressed their sensation of drowsiness, while in another group a fatuous euphoria was conspicuous. Symptoms passed off in about six to eight hours and left no sequelæ, except in one hypochondriacal patient who has continued to complain that the drug has increased her various symptoms.

Appetites were described as ravenous by several subjects. At the height of the intoxication an irregular tremor of the outstretched hands was common, combined with a-tendency to sway in the Romberg test. The hands were cold and clammy, but no unusual vasomotor disturbances were noted. The pulse rate, taken half-hourly throughout the day, showed no consistent raising or lowering.

\section{Details of the Clinical Picture and Their Relation to the Personalities of the Subjects}

Disturbances in Perception and Sensation.-The commonest and most marked changes occurred in somatic sensations. In four subjects depersonalization had been a marked feature of their clinical state, and in all of them the symptom was made worse with synhexyl. Although intensified, the characteristics of a particular subject's feelings of depersonalization did not differ when the subject was under the drug from such characteristics when the subject was not under its influence. Other somatic sensations were those commonly associated with anxiety: palpitations, "tight band round the head," "something in the throat," "trembling in the knees." Five out of the eight patients who showed no depersonalization reported these somatic sensations. For most of the patients they were very unpleasant, and they occurred whether or not the subject had previously had marked anxiety symptoms.

Changes in auditory perception were not reported, but three patients spoke of mild visual disturbances : things looked darker, or dead. One patient (Case 1) reported definite disturbances of time perception. "Time seems unreal. Things keep surprising me, it's like coming out of gas. It's as if everything were a long time ago.".

Case 5.-One patient had a form of hypnogogic experience. She was married and aged 33. Her mother was a domineering strict woman who had remarried after the death of the patient's father when the patient was aged 3. There were step-sibs only. From the age of 5 to 8 years the patient had as a companion a girl cousin who died later, and then for long periods she lived with an aunt and a grandmother. She was a solitary, delicate child with many fears and worries, who never let herself go, and was excessively conscientious but only average at school and clerical work. There was a history from the age of 15 of several attacks of fears, mainly of tuberculosis (which had been suspected in her as a child). The present attack was longer and deeper, with a depressive effect and many obsessional fears and thoughts, mostly about the health and life of her husband and one child.

After taking $40 \mathrm{mg}$. of synhexyl she recounted an interesting vivid hypnogogic experience which she stressed as being more vivid than a dream : "When I dozed off my thoughts seemed to rush back into the past, and I imagined I was going somewhere as I did as a child, down a street in which I lived from the age of 7 to 12 years. I was unhappy because I was sent there for my health and my cousin and step-brother had both died in that street." (This street is near her present home and even now she refuses to walk down it although she thinks of its connexion with her previous life only when she has to pass it.)

The synhexyl made her feel giddy and depressed, and she had palpitations and a drawing feeling at the back of her head. At the height of the drug effect she tended to giggle rather feebly but denied she felt particularly happy. There was no increase in her obsessional thoughts. Benzedrine gave her " a lovely feeling of happiness," and she felt as if she could do things without so much worrying.

This is an interesting example of a person who in childhood was obsessed with many affect-laden thoughts and imaginations which synhexyl allowed to emerge again in semi-consciousness.

Disturbances in Thought Processes.-Some mild degree of lack of concentration was noticed in all subjects, and marked thought disturbances occurred in two or three patients. All of them were aware of the changes but were inaccurate in their estimate of how they were doing on the psychological tests. Several patients (Cases 1, 5, and 10) had histories of obsessional thinking and habits, but this thought disturbance was not seen at all under synhexyl in these or other patients. The following is an example of a fairly marked thought disturbance.

Case 6. - The patient (Case 6) was aged 26. Her mother was hypochondriacal, her father irritable and badtempered. She was the youngest of three, being of normal birth and development, and described as a gay girl with plenty of admirers, but much spoiled and very dependent. As a wife she was suspicious and nagging, constantly accusing her husband of infidelity.' Her build was asthenic, her personality markedly schizoid. Over some months. anxieties and phobias about food had developed, together with obsessional washing rituals, fears of pregnancy, and many hypochondriacal ideas. 
Under the influence of $40 \mathrm{mg}$. synhexyl she showed a peculiar schizophreniform reaction : a few minutes after she had completed the designs test she returned to tell me that she had been listening to symphony music on the radio, "It seemed the only real thing at the time. My husband says I don't like classical music, but he's fond of it and thinks I don't understand it. I feel as if I've completed a picture, not only in the designs but as a person. I feel it is this place really, my husband and child are outside, I am shut away from them in here." She appeared strange, abstracted, preoccupied, and stared vacantly ; she easily burst into tears without any great underlying affect. Later when questioned she was rather giggly. "I really felt as if I had completed a picture with the designs-I suppose it is the idea of the drug to clamp down on you and now I've finished with them." On benzedrine she wanted to sing and felt " as I am sure I normally am. I realize what a disagreeable person I must have been to other people." Her appetite remained good. She was discharged from hospital a few weeks after the trial of synhexyl but little improved. During follow-up in the out-patients' clinic her symptoms remained much the same, with the addition that she blamed the synhexyl now for many of her peculiar feelings and thought disturbances.

Disturbances in Feelings and Emotions.-The relation between the clinical picture and previous personality is here closest ; both in the nature and quality of the affect and in the degree to which the subjects were disturbed. The most labile and immature personalities showed the most marked affective changes, and the picture was in their case the most remote from their normal (pre-morbid) affective state (Cases 1 and 5). On the other hand cases whose patterns of personality breakdown were more fixed showed a picture like their usual, differing only in being more exaggerated in some cases, as is shown, for example, by Cases 2 and 9 .

Case 2.-A woman aged 73 had a normal birth and development, but had an unhappy home owing to her mother's remarriage to a chronic alcoholic. She secretly married a Frenchman, and for most of their married life they lived apart in their respective countries. In spite of this she has carried on, a quiet and stable woman, rearing several children, until at the age of 71 the slow onset of depression without any evidence of intellectual deterioration. Investigation of recent stomach pains and indigestion revealed an incidental carcinoma of the stomach. Her reaction to $30 \mathrm{mg}$. synhexyl was to feel just tired with some slowing of thought. The bigger dose produced more definite nervousness and giddy feelings. Objectively she appeared but little changed, perhaps a little shakier in handwriting and rather easily confused in the psychological tests. With benzedrine she felt better and not so nervous but there was little objective change.

Case 9, aged 44, was the daughter of a clergymanschoolmaster, a rather anxious person who has probably suffered from depressive episodes. One brother suffered from postoperative depression, another committed suicide. She developed normally at school and university and she now holds a professional qualification and has been doing well, though not brilliantly. She has had two unhappy love affairs. In the past two years she has had four periods in hospital with acute depression, and more than one attempt at suicide. She appears to have been a chronically anxious, worried, introspective person with little self-confidence and self-insight. Synhexyl was given when the patient had somewhat improved after four therapeutic electrical convulsions. On the smaller dose she began to feel " giddy and muzzy, a pleasant feeling if one hadn't anything to do." In manner she appeared a little elated and hearty. With 40 mg. she felt very sleepy and faintly giddy "rather like the first stages of intoxication"-though "drinks" normally make her "chatty" which was not a feature of her reaction on this occasion. On benzedrine she felt "quite full of beans and not sleepy as yesterday."

Although under the influence of synhexyl many of the patients were " giggly," given to making feeble jokes and laughing immoderately at very little, the prevailing affective response was one of apprehension, and in retrospect only two patients said the sensation was at all enjoyable (Cases 9 and 3). Case 3 was the only one in whom any real clinical improvement followed administration of the drug.

Case 3.-A woman aged 40, was the daughter of a street trader. She had a normal birth and development but was always considered highly-strung and excitable. She married at 23 and has one child aged 16 . Her husband is dull, irresponsible, and often out of work. The patient has had much worry and responsibility, which she has succeeded in carrying competently, until her first breakdown after the birth of her baby sixteen years ago. A second breakdown in 1945 was precipitated by a blood transfusion. She had several anxiety attacks resembling faints, and when drowsy she had sensations of falling and of whispering voices. At the time of this breakdown she was admitted to hospital. She was mildly confused from a self-administered overdose of barbiturates ; but this state cleared up, leaving a depressed, emotional, agitated picture. She improved, but soon relapsed on return to her unsatisfactory social condition, and she returned to hospital a few months later. The symptoms on this occasion were more dramatic. Whispering voices, and faces grinning at her as night fell, were prominent hypnogogic symptoms. She was histrionic in general behaviour and preoccupied with her wickedness and guilt. Before synhexyl was given she had had a course of modified insulin treatment with improvement, marked especially by the disappearance of the hypnogogic hallucinations. She became a popular member of the ward and a sympathetic listener to other patient's troubles, although in relation to the doctor she was still full of her own. At 1.30 p.m. on the day when $30 \mathrm{mg}$. synhexyl was given she said, "I feel worried because I can't worry over anything." Later that afternoon she said "For the first time for a long time I feel comfortably tired." She had-and this was unusual for her-been lying on her bed in the afternoon. She was asked to close her eyes, but no 
hypnogogic imagery was called up. She remarked-that the "faces" only occurred at night. After the larger dose of synhexyl she felt even more comfortable and drowsy, "living in the clouds" ; but the next day she wrote, "In the early evening (of yesterday) I felt kind of anxious and panicky, afraid to think and wanted to keep on pushing my thoughts away, thankful to go to the social to help stop myself giving way to doubts and fears again and that feeling of mistrust. I slept much better during the night."

In view of the improvement she was given $20 \mathrm{mg}$. synhexyl twice daily and remained happy and comfortable for some days. She went home for the week-end, back to the same old difficulties; and in spite of continuing to take her tablets she relapsed and returned to her former condition. However, she said she felt sufficiently encouraged " to try again," so she left hospital, but when seen in the out-patients' clinic she was in much the same state of agitation as before.

This patient is also of interest in being the only one made definitely worse with benzedrine. "I've a horrible feeling I'm not doing so well as I should, everything is an effort." It began just before lunch when she did not want to eat and could not be bothered with anybody. Since 11.30 a.m., two-and-a-half hours after the drug, she developed spasms of shivering, feeling cold in her head and body, and needed a hot drink and extra jacket. She wanted to keep on doing things "to hang on to myself. I don't feel as though I'm here." She denied ever having had such feelings before.

Disturbances in Consciousness. - With the larger dose of synhexyl nearly all the patients showed some clouding of consciousness. Several said they felt strange and floating in and out of the world. Giddiness, remarked on by half the subjects, fluctuated in intensity during the course of the drug effect. Five patients were markedly drowsy, and dozed in the afternoon, contrary to their usual custom. Case 3 enjoyed the lightness and vagueness of the cloudy state; but the others, who did not take refuge in sleep, were disturbed by the unsteadiness it brought about.

Case 1.-This patient, aged 24, is the daughter of a dentist and a domineering histrionic mother. There is a history of insanity on the father's side. She was a premature baby but developed normally and did well at school. She began a medical career, getting only as far as the beginning of the anatomy course. Since then she has had various jobs closely related to home. She is a generally immature, dependent, querulous girl with a history of various obsessional phenomena in her teens. Presenting symptoms were mild anorexia nervosa and a tendency to vasomotor rhinorrhœa, a fear of " hayfever ". being prominent in her mental state. Physical immaturity was quite marked, especially in the development of the breasts and hair. After $30 \mathrm{mg}$. synhexyl she said, "I feel absolutely terrified, and frightened for my sanity." She looked depressed and worried, her thoughts moved more slowly, concentration was difficult, and she felt generally remote and drowsy, when not anxious. She felt she had improved in the mental tests, which was not so. With $\mathbf{4 0} \mathrm{mg}$. synhexyl she felt remote and dazed. "I kept drifting off and coming back into the conversation. It is as if everything was a long time ago. When I left the dormitory for a moment and then returned I was surprised to find they were still talking about the same thing. Things don't seem joined together. I have to concentrate on being here. I can see now the Ward Sister coming in to tell me to come to see you here, it's in my mind, not a delusion."

She said she felt happier than with $30 \mathrm{mg}$. of synhexyl, " but to-day I am so gone out that I don't sort of feel anything." In her manner she appeared the most intoxicated of all the subjects, markedly unsteady on her feet, grinning and giggling fatuously, hardly able to co-operate on the tests. The relatively severe reaction to synhexyl is clearly related to her poor previous personality, which easily crumbled with any stress. It is interesting that no obsessional symptoms were noted. Her appetite was "ravenous," anorexia being the only symptoms which could really be said to have improved. On benzedrine she felt happier and brighter, she sought out people to talk to, and in the test situation she was more outgoing, talked louder, and smiled more.

Disturbance in Conation and Will-Power.-This needs only brief mention as it will be discussed in relation to the persistence test. All subjects showed a decreased interest in work and were content to doze or sit about. They found their attention wandering from the psychological tests.

\section{Psychological Tests}

The Battery of Tests.-The battery of tests given consisted of :

An adding test (of the old Kraepelinian variety).-In this the subject has to add together groups of two single digits, writing down only the second digit if the total is more than 10 e.g., $6+3=9 ; 8+9=7$. The numbers are arranged in columns and the subject adds continuously for five minutes, drawing a line at the point he has reached when the examiner calls every thirty seconds. In this way a work curve is obtained of six consecutive thirty-second periods of addition.

A perseveration test (taken from Cattell's (1946) battery).-The three sub-tests chosen were those with the highest factor saturation : that is, writing the subject's own name forwards and backwards, writing three digits forwards and backwards, and a five-letter word forwards and backwards for one minute in each direction. A new combination of digits and a different word was used for every test occasion. The score is the ratio of words or letters written forwards to those written backwards.

$A$ concentration test (adapted from one being investigated by Dr. Eysenck). - The examiner reads out a string of random numbers and at irregular intervals calls "Now." The subject then has to remember the preceding two numbers called out. "Now" is called out four times, and at the last the subject has to write down all eight numbers he has been expected to remember. 
TABLE I

ADDING TESTS : TOTAL FIVE-MINUTES SCORES

\begin{tabular}{|c|c|c|c|c|c|c|c|c|c|c|c|}
\hline \multirow{2}{*}{$\begin{array}{l}\text { Drug and } \\
\text { dose }\end{array}$} & \multirow{2}{*}{ Time } & \multicolumn{9}{|c|}{ Case } & \multirow{2}{*}{ Average } \\
\hline & & 1 & 2 & 3 & 4 & 5 & 6 & 7 & 8 & 9 & \\
\hline $\begin{array}{l}\text { Synhexyl } \\
30 \mathrm{mg} \text {. }\end{array}$ & $\begin{array}{l}9.00 \text { a.m. } \\
1.30 \text { p.m. } \\
3.30 \text { p.m. }\end{array}$ & $\begin{array}{r}102 \\
89 \\
111\end{array}$ & $\begin{array}{l}65 \\
53 \\
59\end{array}$ & $\begin{array}{r}108 \\
83 \\
91\end{array}$ & $\begin{array}{l}104 \\
108 \\
117\end{array}$ & $\begin{array}{r}72 \\
100 \\
114\end{array}$ & $\begin{array}{r}84 \\
113 \\
116\end{array}$ & $\begin{array}{r}96 \\
108 \\
112\end{array}$ & $\begin{array}{l}125 \\
117 \\
136\end{array}$ & $\begin{array}{l}166 \\
172 \\
167\end{array}$ & $\begin{array}{l}102 \\
105 \\
108\end{array}$ \\
\hline $\begin{array}{l}\text { Benzedrine } \\
20 \mathrm{mg} \text {. }\end{array}$ & $\begin{array}{l}9.00 \text { a.m. } \\
1.30 \text { p.m. } \\
3.30 \text { p.m. }\end{array}$ & $\begin{array}{c}145 \\
136 \\
-\end{array}$ & $\begin{array}{l}67 \\
63 \\
-\end{array}$ & $\begin{array}{l}67 \\
72 \\
-\end{array}$ & $\begin{array}{l}86 \\
98 \\
-\end{array}$ & $\begin{array}{l}115 \\
138 \\
148\end{array}$ & $\begin{array}{l}145 \\
164 \\
155\end{array}$ & E & $\begin{array}{l}164 \\
178 \\
-\end{array}$ & $\begin{array}{l}204 \\
203 \\
-\end{array}$ & $\begin{array}{l}124 \\
132 \\
-\end{array}$ \\
\hline $\begin{array}{l}\text { Synhexyl } \\
40 \mathrm{mg} \text {. }\end{array}$ & $\begin{array}{l}9.00 \text { a.m. } \\
1.30 \text { p.m. } \\
3.30 \text { p.m. }\end{array}$ & $\begin{array}{l}118 \\
107 \\
105\end{array}$ & $\begin{array}{l}74 \\
62 \\
84\end{array}$ & $\begin{array}{l}70 \\
48 \\
47\end{array}$ & $\begin{array}{l}143 \\
140 \\
138\end{array}$ & $\begin{array}{l}154 \\
152 \\
159\end{array}$ & $\begin{array}{l}171 \\
144 \\
149\end{array}$ & $\begin{array}{l}118 \\
110 \\
114\end{array}$ & $\begin{array}{l}158 \\
133 \\
198\end{array}$ & $\begin{array}{l}197 \\
184 \\
198\end{array}$ & $\begin{array}{l}134 \\
120 \\
132\end{array}$ \\
\hline
\end{tabular}

TABLE II

PERSEVERATION SCORES FOR FIVE-LETTER WORD : RATIO FORWARDS/BACKWARDS

\begin{tabular}{|c|c|c|c|c|c|c|c|c|c|c|c|}
\hline \multirow{2}{*}{$\begin{array}{l}\text { Drug and } \\
\text { dose }\end{array}$} & \multirow{2}{*}{ Time } & \multicolumn{9}{|c|}{ Case } & \multirow{2}{*}{ Average } \\
\hline & & 1 & 2 & 3 & 4 & 5 & 6 & 7 & 8 & 9 & \\
\hline $\begin{array}{l}\text { Synhexyl } \\
30 \mathrm{mg} \text {. }\end{array}$ & $\begin{array}{l}9.00 \text { a.m. } \\
1.30 \text { p.m. } \\
3.30 \text { p.m. }\end{array}$ & $\begin{array}{l}4 \cdot 2 \\
6 \cdot 8 \\
4 \cdot 3\end{array}$ & $\begin{array}{c}7 \cdot 5 \\
11 \\
6 \cdot 5\end{array}$ & $\begin{array}{l}6 \\
5 \cdot 3 \\
6\end{array}$ & $\begin{array}{l}4 \cdot 6 \\
6 \cdot 8 \\
6 \cdot 8\end{array}$ & $\begin{array}{l}6 \cdot 8 \\
5 \cdot 2 \\
4\end{array}$ & $\begin{array}{l}5 \cdot 4 \\
4 \cdot 8 \\
7\end{array}$ & $\begin{array}{l}7 \\
6 \\
4 \cdot 5\end{array}$ & $\begin{array}{l}8 \\
4 \cdot 5 \\
3 \cdot 3\end{array}$ & $\begin{array}{l}6 \cdot 8 \\
8 \cdot 5 \\
9\end{array}$ & $\begin{array}{l}6 \cdot 1 \\
6 \cdot 5 \\
5 \cdot 9\end{array}$ \\
\hline $\begin{array}{l}\text { Benzedrine } \\
20 \mathrm{mg} \text {. }\end{array}$ & $\begin{array}{l}9.00 \text { a.m. } \\
1.30 \text { p.m. } \\
3.30 \text { p.m. }\end{array}$ & $\begin{array}{l}4 \\
5 \\
-\end{array}$ & $\begin{array}{c}5 \cdot 3 \\
15 \\
-\end{array}$ & $\begin{array}{l}7 \\
7 \cdot 5 \\
-\end{array}$ & $\begin{array}{l}7 \cdot 5 \\
8 \cdot 7 \\
-\end{array}$ & $\begin{array}{l}6 \\
4 \cdot 5 \\
7 \cdot 8\end{array}$ & $\begin{array}{l}6 \cdot 2 \\
5 \cdot 3 \\
6\end{array}$ & E & $\begin{array}{l}3 \cdot 7 \\
4 \cdot 6 \\
-\end{array}$ & $\begin{array}{l}4 \cdot 3 \\
5 \cdot 3 \\
-\end{array}$ & $\begin{array}{l}5 \cdot 5 \\
7 \cdot 1 \\
-\end{array}$ \\
\hline $\begin{array}{l}\text { Synhexyl } \\
40 \text { mg. }\end{array}$ & $\begin{array}{l}9.00 \text { a.m. } \\
1.30 \text { p.m. } \\
3.30 \text { p.m. }\end{array}$ & $\begin{array}{l}3 \\
3 \cdot 8 \\
4 \cdot 3\end{array}$ & $\begin{array}{l}5 \cdot 7 \\
3 \cdot 7 \\
7 \cdot 5\end{array}$ & $\begin{array}{l}4 \cdot 4 \\
4 \cdot 4 \\
6\end{array}$ & $\begin{array}{l}5 \cdot 0 \\
5 \cdot 2 \\
5 \cdot 8\end{array}$ & $\begin{array}{l}3 \cdot 7 \\
5 \cdot 8 \\
8\end{array}$ & $\begin{array}{l}6 \\
8 \\
4 \cdot 3\end{array}$ & $\begin{array}{l}5 \cdot 8 \\
3 \cdot 6 \\
5 \cdot 2\end{array}$ & $\begin{array}{l}5 \cdot 7 \\
3 \cdot 9 \\
4\end{array}$ & $\begin{array}{l}4 \cdot 7 \\
5 \cdot 1 \\
5 \cdot 3\end{array}$ & $\begin{array}{l}4 \cdot 9 \\
4 \cdot 8 \\
5 \cdot 6\end{array}$ \\
\hline
\end{tabular}

TABLE III

CONCENTRATION TEST (SUM TOTALS OF FIGURES AND LETTERS RECALLED)

\begin{tabular}{|c|c|c|c|c|c|c|c|c|c|c|c|}
\hline \multirow{2}{*}{$\begin{array}{l}\text { Drug and } \\
\text { dose }\end{array}$} & \multirow{2}{*}{ Time } & \multicolumn{9}{|c|}{ Case } & \multirow{2}{*}{ Average } \\
\hline & & 1 & 2 & 3 & 4 & 5 & 6 & 7 & 8 & 9 & \\
\hline $\begin{array}{l}- \text { Synhexyl } \\
30 \mathrm{mg} \text {. }\end{array}$ & $\begin{array}{l}9.00 \text { a.m. } \\
1.30 \text { p.m. } \\
3.30 \text { p.m. }\end{array}$ & $\begin{array}{l}16 \\
15 \\
15\end{array}$ & $\begin{array}{l}3 \\
3 \\
5\end{array}$ & $\begin{array}{l}14 \\
12 \\
15\end{array}$ & $\begin{array}{l}12 \\
13 \\
11\end{array}$ & $\begin{array}{l}15 \\
13 \\
13\end{array}$ & $\begin{array}{r}14 \\
10 \\
4\end{array}$ & $\begin{array}{r}12 \\
5 \\
6\end{array}$ & $\begin{array}{r}14 \\
5 \\
6\end{array}$ & $\begin{array}{r}14 \\
14 \\
9\end{array}$ & $\begin{array}{c}12 \cdot 3 \\
10 \\
9 \cdot 3\end{array}$ \\
\hline $\begin{array}{l}\text { Benzedrine } \\
20 \mathrm{mg} \text {. }\end{array}$ & $\begin{array}{l}9.00 \text { a.m. } \\
1.30 \text { p.m. } \\
3.30 \text { p.m. }\end{array}$ & $\begin{array}{l}16 \\
15 \\
-\end{array}$ & $\begin{array}{r}9 \\
8 \\
-\end{array}$ & $\begin{array}{l}12 \\
13 \\
-\end{array}$ & $\begin{array}{l}16 \\
13 \\
-\end{array}$ & $\begin{array}{l}15 \\
13 \\
14\end{array}$ & $\begin{array}{l}13 \\
12 \\
10\end{array}$ & 二 & $\begin{array}{r}6 \\
9 \\
-\end{array}$ & $\begin{array}{l}16 \\
13 \\
-\end{array}$ & $\begin{array}{l}12 \cdot 9 \\
12 \\
-\end{array}$ \\
\hline $\begin{array}{l}\text { Synhexyl } \\
40 \mathrm{mg} \text {. }\end{array}$ & $\begin{array}{l}9.00 \text { a.m. } \\
1.30 \text { p.m. } \\
3.30 \text { p.m. }\end{array}$ & $\begin{array}{l}15 \\
13 \\
14\end{array}$ & $\begin{array}{r}9 \\
8 \\
16\end{array}$ & $\begin{array}{r}14 \\
9 \\
14\end{array}$ & $\begin{array}{r}16 \\
9 \\
11\end{array}$ & $\begin{array}{l}19 \\
10 \\
14\end{array}$ & $\begin{array}{r}7 \\
8 \\
13\end{array}$ & $\begin{array}{r}9 \\
11 \\
13\end{array}$ & $\begin{array}{l}6 \\
5 \\
2\end{array}$ & $\begin{array}{l}16 \\
16 \\
10\end{array}$ & $\begin{array}{r}12 \cdot 3 \\
9 \cdot 9 \\
11 \cdot 8\end{array}$ \\
\hline
\end{tabular}

N.B.-Cases 5 and 6 , tested together, proved to score full marks when required to remember eight letters and eight figures. Their scores, therefore, are the number of figures and letters remembered out of ten letters and ten figures. 
TABLE IV

LENGTH OF TIME TEST

\begin{tabular}{|c|c|c|c|c|c|c|c|c|c|c|c|}
\hline \multirow{2}{*}{$\begin{array}{l}\text { Drug and } \\
\text { dose }\end{array}$} & \multirow[b]{2}{*}{ Time } & \multicolumn{9}{|c|}{ Case } & \multirow{2}{*}{ Average } \\
\hline & & 1 & 2 & 3 & 4 & 5 & 6 & 7 & 8 & 9 & \\
\hline $\begin{array}{l}\text { Synhexyl } \\
30 \mathrm{mg} \text {. }\end{array}$ & $\begin{array}{l}9.00 \text { a.m. } \\
1.30 \text { p.m. } \\
3.30 \text { p.m. }\end{array}$ & $\begin{array}{l}32 \\
35 \\
29\end{array}$ & $\begin{array}{l}30 \\
29 \\
26\end{array}$ & $\begin{array}{l}35 \\
49 \\
30\end{array}$ & $\begin{array}{l}41 \\
36 \\
33\end{array}$ & $\begin{array}{l}29 \\
35 \\
25\end{array}$ & $\begin{array}{l}34 \\
29 \\
33\end{array}$ & $\begin{array}{l}31 \\
35 \\
32\end{array}$ & $\begin{array}{l}24 \\
15 \\
13\end{array}$ & $\begin{array}{l}30 \\
42 \\
32\end{array}$ & $\begin{array}{l}32 \\
34 \\
28\end{array}$ \\
\hline $\begin{array}{l}\text { Benzedrine } \\
20 \mathrm{mg} \text {. }\end{array}$ & $\begin{array}{l}9.00 \text { a.m. } \\
1.30 \text { p.m. } \\
3.30 \text { p.m. }\end{array}$ & $\begin{array}{r}35 \\
34 \\
-\end{array}$ & $\begin{array}{l}24 \\
30 \\
-\end{array}$ & $\begin{array}{l}36 \\
28 \\
-\end{array}$ & $\begin{array}{r}35 \\
37 \\
-\end{array}$ & $\frac{29}{-}$ & $\begin{array}{l}33 \\
33 \\
29\end{array}$ & $\frac{34}{-}$ & $\begin{array}{l}16 \\
15 \\
-\end{array}$ & $\begin{array}{l}29 \\
31 \\
-\end{array}$ & $\begin{array}{l}30 \\
26 \\
-\end{array}$ \\
\hline $\begin{array}{l}\text { Synhexyl } \\
40 \mathrm{mg} \text {. }\end{array}$ & $\begin{array}{l}9.00 \text { a.m. } \\
1.30 \text { p.m. } \\
3.30 \text { p.m. }\end{array}$ & $\begin{array}{l}32 \\
28 \\
30\end{array}$ & $\begin{array}{l}\overline{30} \\
25\end{array}$ & $\begin{array}{l}29 \\
28 \\
36\end{array}$ & $\begin{array}{l}40 \\
36 \\
36\end{array}$ & $\begin{array}{l}29 \\
31 \\
24\end{array}$ & $\begin{array}{l}34 \\
29 \\
29\end{array}$ & $\begin{array}{l}38 \\
28 \\
27\end{array}$ & $\begin{array}{l}14 \\
10 \\
13\end{array}$ & $\begin{array}{l}33 \\
36 \\
29\end{array}$ & $\begin{array}{l}31 \\
28 \\
27\end{array}$ \\
\hline
\end{tabular}

TABLE $\mathbf{V}$

TIME OF LEG-RAISING (PERSISTENCE TEST) (IN SECONDS)

\begin{tabular}{|c|c|c|c|c|c|c|c|c|c|c|c|}
\hline \multirow{2}{*}{$\begin{array}{l}\text { Drugs and } \\
\text { dose }\end{array}$} & \multirow{2}{*}{ Time } & \multicolumn{9}{|c|}{ Case } & \multirow{2}{*}{ Average $\frac{7}{\pi}$} \\
\hline & & 1 & 2 & 3 & 4 & 5 & 6 & 7 & 8 & 9 & \\
\hline $\begin{array}{l}\text { Synhexyl } \\
30 \mathrm{mg} \text {. }\end{array}$ & $\begin{array}{l}9.00 \text { a.m. } \\
1.30 \text { p.m. } \\
3.30 \text { p.m. }\end{array}$ & $\begin{array}{l}930 \\
280 \\
165\end{array}$ & $\begin{array}{l}54 \\
30 \\
64\end{array}$ & $\begin{array}{l}20 \\
17 \\
20\end{array}$ & $\begin{array}{l}38 \\
30 \\
34\end{array}$ & $\begin{array}{r}130 \\
35 \\
108\end{array}$ & $\begin{array}{r}115 \\
93 \\
285\end{array}$ & $\begin{array}{r}107 \\
65 \\
82\end{array}$ & $\begin{array}{l}30 \\
53 \\
65\end{array}$ & $\begin{array}{l}78 \\
56 \\
43\end{array}$ & $\begin{array}{r}167 \\
73 \\
96\end{array}$ \\
\hline $\begin{array}{l}\text { Benzedrine } \\
20 \mathrm{mg} \text {. }\end{array}$ & $\begin{array}{l}9.00 \text { a.m. } \\
1.30 \text { p.m. } \\
3.30 \text { p.m. }\end{array}$ & $\begin{array}{r}1500 \\
770 \\
- \\
\end{array}$ & $\begin{array}{r}100 \\
88 \\
-\end{array}$ & $\begin{array}{l}34 \\
28 \\
-\end{array}$ & $\begin{array}{l}30 \\
35 \\
-\end{array}$ & $\frac{186}{195}$ & $\begin{array}{r}930 \\
.1445 \\
590\end{array}$ & $\frac{67}{-}$ & $\begin{array}{l}48 \\
60 \\
-\end{array}$ & $\begin{array}{l}93 \\
56 \\
-\end{array}$ & $\begin{array}{c}332 \\
366 \\
-\quad\end{array}$ \\
\hline $\begin{array}{l}\text { Synhexyl } \\
40 \mathrm{mg} \text {. }\end{array}$ & $\begin{array}{l}9.00 \text { a.m. } \\
1.30 \text { p.m. } \\
3.30 \text { p.m. }\end{array}$ & $\begin{array}{l}930 \\
345 \\
405\end{array}$ & $\begin{array}{r}108 \\
42 \\
44\end{array}$ & $\begin{array}{l}33 \\
20 \\
38\end{array}$ & $\begin{array}{r}44 \\
30 \\
31\end{array}$ & $\begin{array}{r}120 \\
100 \\
95\end{array}$ & $\begin{array}{r}1060 \\
435 \\
505\end{array}$ & $\begin{array}{l}45 \\
46 \\
26\end{array}$ & $\begin{array}{l}34 \\
26 \\
34\end{array}$ & $\begin{array}{l}90 \\
30 \\
60\end{array}$ & $\begin{array}{l}274 \\
119 \\
137\end{array}$ \\
\hline
\end{tabular}

TABLE VI

TIME OF BREATH-HOLDING (IN SECONDS)

\begin{tabular}{|c|c|c|c|c|c|c|c|c|c|c|c|}
\hline \multirow{2}{*}{$\begin{array}{c}\text { Drug and } \\
\text { dose }\end{array}$} & \multirow{2}{*}{ Time } & \multicolumn{9}{|c|}{ Case } & \multirow{2}{*}{ Average } \\
\hline & & 1 & 2 & 3 & 4 & 5 & 6 & 7 & 8 & 9 & \\
\hline $\begin{array}{l}\text { Synhexyl } \\
30 \mathrm{mg} \text {. }\end{array}$ & $\begin{array}{l}9.00 \text { a.m. } \\
1.30 \text { p.m. } \\
3.30 \text { p.m. }\end{array}$ & $\begin{array}{l}84 \\
60 \\
63\end{array}$ & $\begin{array}{l}28 \\
29 \\
25\end{array}$ & $\begin{array}{r}8 \\
8 \\
11\end{array}$ & $\begin{array}{l}24 \\
31 \\
35\end{array}$ & $\begin{array}{l}38 \\
23 \\
44\end{array}$ & $\begin{array}{l}47 \\
35 \\
30\end{array}$ & $\begin{array}{l}30 \\
40 \\
35\end{array}$ & $\begin{array}{l}23 \\
25 \\
28\end{array}$ & $\begin{array}{l}30 \\
29 \\
36 \\
\end{array}$ & $\begin{array}{l}35 \\
31 \\
34 \\
\end{array}$ \\
\hline $\begin{array}{l}\text { Benzedrine } \\
20 \mathrm{mg} \text {. }\end{array}$ & $\begin{array}{l}9.00 \text { a.m. } \\
1.30 \text { p.m. } \\
3.30 \text { p.m. }\end{array}$ & $\begin{array}{l}64 \\
75 \\
-\end{array}$ & $\begin{array}{l}22 \\
22 \\
-\end{array}$ & $\begin{array}{l}10 \\
12 \\
-\end{array}$ & $\begin{array}{l}35 \\
35 \\
-\end{array}$ & $\frac{41}{44}$ & $\begin{array}{l}32 \\
37 \\
46\end{array}$ & $\frac{34}{-}$ & $\begin{array}{l}37 \\
20 \\
-\end{array}$ & $\begin{array}{l}36 \\
31 \\
-\end{array}$ & $\begin{array}{l}34 \\
33 \\
\end{array}$ \\
\hline $\begin{array}{l}\text { Synhexyl } \\
40 \mathrm{mg} .\end{array}$ & $\begin{array}{l}9.00 \text { a.m. } \\
1.30 \text { p.m. } \\
3.30 \text { p.m. }\end{array}$ & $\begin{array}{l}46 \\
75 \\
73\end{array}$ & $\begin{array}{l}22 \\
28 \\
30\end{array}$ & $\begin{array}{r}8 \\
10 \\
17\end{array}$ & $\begin{array}{l}40 \\
30 \\
37\end{array}$ & $\begin{array}{l}31 \\
40 \\
32\end{array}$ & $\begin{array}{l}47 \\
33 \\
44\end{array}$ & $\begin{array}{l}31 \\
28 \\
25\end{array}$ & $\begin{array}{l}16 \\
13 \\
13\end{array}$ & $\begin{array}{l}33 \\
37 \\
24\end{array}$ & $\begin{array}{l}30 \\
33 \\
33\end{array}$ \\
\hline
\end{tabular}


Length of time test.-The examiner makes two taps on the table five seconds apart and asks the subject to tap out the same interval of time. The subject has to tap out six consecutive five-second periods, so that in this way any tendency to increase or decrease of time length is magnified.

Designs test.-This was more in the nature of an experiment. In organic disturbances, as has been pointed out by Mayer-Gross and Guttmann (1936), there is a difference between spontaneity and poverty of ideas which the ordinary fluency tests would confuse. The following test was devised by Dr. Guttmann in the hope that some distinction might be made between total productivity and the quality of the productions. The subject is given six wooden blocks of different colours and flat shapes (for example, red triangles; blue rectangle, black parallelogram) and in two minutes she has to make as many new designs as possible. The total number of designs was considered to be related in some ways to spontaneity, and the character of the designs, such as tendencies toward making them stereotyped, etc., related to " poverty of ideas."

Persistence tests (as worked out by Dr. Eysenck, 1947).- In the first the subject has to hold her leg outstretched just above a chair seat for as long as possible without holding it with her hand or otherwise supporting it. The score is the length of time until the leg drops on to the chair. In the second the subject has to hold her breath for as long as possible.

Several other tests were tried out with one or two groups, such as other fluency tests (rhymes to a given word, efc.) and cancellation tests, but they yielded such irregular results as would be useless for investigation of the drug effect. The main difficulty encountered in devising suitable tests arose from the subjects' having to do them so many times-three times a day for three or four days - that learning and general practice effects dominated the changes in scores:

Results of the Psychological Tests.-Table I shows the total scores of the five-minute adding periods. Comparison of the 9 a.m. scores shows that marked improvement with practice occurred in most subjects during the test week. The 1.30 p.m. scores, however, are higher in all but two subjects on the benzedrine day than on the synhexyl days."

There was also an increased number of errors made by most subjects on the synhexyl days. Although not statistically significant, these results suggest that such effect as synhexyl has on intellectual activity impairs rather than improves it. It is interesting to note that Case 3 , the one patient reporting general clinical improvement, nevertheless showed a falling off of work output at 1.30 p.m.

In Table II, practice effects overshadowed any statistically significant effects from other causes: The ratio of forward- to backward-written words and figures decreased steadily throughout the week.
Under benzedrine the total number of words written, forwards and backwards, tended to be larger than under synhexyl. 'The trend in most subjects was for the ratio to rise with synhexyl, suggesting an increase in perseveration, or disposition rigidity as Cattell calls it. . This trend was seen clearly only in the scores for the five-letter word, where practice is clearly least important, and Table II gives the values for this part of the test. This is of interest in that the clinical type Cattell describes as associated with high perseveration corresponds more closely to the synhexyl picture than does his low-perseveration type.

The defective will-power factor, as suggested by the persistence tests, would also tend to increase perseveration.

Table III gives the combined totals of figures and numbers recalled. The total remembered at the 1.30 p.m. tests is lower than either the 9 a.m. or 3.30 p.m. with both drugs, though the fall is greater with synhexyl than benzedrine. Again it is to be noted that the patient reporting improvement (3) did not do so well with synhexyl as with benzedrine.

Table IV gives the total time taken to tap out the six consecutive five-second periods. The overall picture shows no consistent changes, though the smaller dose of synhexyl tended to produce a longer time than the larger dose. It is interesting that Case 8 , the most bizarre and psychotic at the time of testing, though her general personality was not the most unstable, gave consistent readings well below the true time and out of the range of the readings of the others. Case 6, who reported the clearest alteration of time perception, showed no significant change in this test. These negative results confirm Morrow's results in the New York report (1944) obtained by a slightly different technique.

In Table $\mathrm{V}$ the creative range of the block was not large enough to make any difference discernible in the quality of the designs produced. The mental set adopted by the subjects to the blocks remained relatively constant throughout the week and depended largely on what they felt to constitute a " different "design. More than one subject adopted the technique of making a basic pattern from most of the blocks and moving one block around it to make " new" designs. Others took "different" seriously and began from scratch on each new design. Interesting as these observations were from the point of view of personality differences, they told nothing of the action of the drug. However, the idea of the relatively free situation would seem to have possibilities.

The leg-raising tests (Table VI) showed the most unequivocal results, all subjects showing a fall in the time they held their legs up on synhexyl. With 
benzedrine a less marked rise in time was noticed. Several factors appear to be at work in producing these results. The demeanour of the patients suggested that the desire to please the doctor by doing. well was an important factor in the length of time they held their legs up: Therefore when made worse with the synhexyl they expressed their thinly-veiled hostility by not trying so hard. Their general sleepiness and withdrawal of interest were other factors. In contrast, the breath-holding time (Table VII) showed little change throughout, presumably because imperative physiological needs allow such a short time for these psychological factors to operate.

\section{Clinical Picture Produced by Synhexyl}

The clinical picture produced by synhexyl may now be summarized as showing :

(1) an impairment of motor co-ordination and a lowering of psychomotor activity ;

(2) an increase in affective experiences and their physiological concomitants ;

(3) a withdrawal of interest from reality to fantasy ;

(4) a blunting of the finer intellectual processes ;

(5) a lowering of the will-power and concentration ;

(6) an impairment of the processes of perception ;

(7) clouding of consciousness.

It may be objected that these are all symptoms of an overdose, above therapeutic levels, but on the first group doses of 10 and $20 \mathrm{mg}$. were given with effects differing only in being less intense or negligible ; they were in no way qualitatively different. There is no evidence of a phase of improved performance before deterioration set in, as there is in some people after small doses of alcohol (Kürz and Kraepelin, 1901). A more serious objection to these findings as representative of the general effect of synhexyl is that subjects, predominantly depressed, tend to exaggerate unpleasant symptoms and minimize the more pleasant, but there is no evidence that the depressive state in itself is liable to make the action of a drug totally different. Kant (1930) gave hashish to a number of manic-depressives and schizophrenics on recovery from the acute phase of their illness and found that the former reacted by depression and increased or decreased psychomotor activity, whereas the latter were euphoric and often showed catatonic symptoms. The difference between the results of the present study and those reported by Stockings (1947) is more difficult to understand, but it is probable that the two groups of patients differed somewhat. Stockings' patients reported undesirable side effects, as ours did, especially in the earlier stages of drug effect, and in the later stages showed euphoria. Several of our patients were certainly euphoric at the height of the drug action, but in the fatuous, insightless, confused manner of the slightly " tipsy."

There would appear to be a difference of opinion about the nature of euphoria and its therapeutic usefulness. Even the word "euphoria" appears to be undergoing a change of meaning, from its original sense of normal bodily well-being to a sense of abnormal well-being such as characteristically occurs in alcoholic intoxication.

\section{Comparison of Synhexyl and Benzedrine Effects}

It is unnecessary even to summarize the wellknown effects of benzedrine which are described in numerous papers. The effects of synhexyl and benzedrine in this group of subjects were in marked contrast, not only in that most subjects were made worse by the former and improved by the latter, but also, as has been mentioned previously, in that the one subject improved by synhexyl was made worse by benzedrine. It is difficult to think of any adequate explanation of this phenomenon, and any speculations along the lines of a sympathetic parasympathetic imbalance are unfortunatel ${ }^{\circ}$ unsupported by any evidence that synhexyl has any parasympathetic activity. Neither is anything known about the metabolism of synhexyl which would link it with the biochemical effects observed by Mann and Quastel (1940). Loewe (1944 reports that in animals benzedrine has a marked. potentiating effect on the ataxia produced by $\overrightarrow{0}$ marihuana; but, as in this series the drugs were $\stackrel{+}{+}$ administered on different days, there are no data relevant to his observations.

From the therapeutic point of view this small series clearly shows the superiority of benzedrine over synhexyl in alleviating depressive states. The psychological tests also show that synhexyl has a more deleterious effect on performance and efficiency than benzedrine. The most marked contrast is seen in the persistence tests, but small effects are noticeable in the adding, concentration, and perseveration tests. The undesirable side effects of synhexyl seem a high price to pay for the doubtful therapeutic value of euphoria and an easing of obsessional thought pressure.

\section{Mode of Action of Marihuana Derivatives and Homologues on the Central Nervous} System

A large number of marihuana derivatives and their homologues have been studied, synhexyl being chosen as the most active of these. The tests employed in their assay are all biological, and only 
one - the amount required to produce ataxia in dogs - is at all reliable. Other methods of assaybased for example on a synergistic hypnotic action in the mouse, or the production of corneal areflexia in the rabbit-have been shown to be due to compounds in marihuana not closely related to synhexyl. During assays in dogs, convulsant spasms are reported to be of frequent occurrence, and at least one derivative has a marked tendency to produce epileptic fits. Detailed studies of the relation between chemical structure and pharmacological activity are summarized by Loewe in the New York report (1944) and do not concern us here. Further reviews have been given by Todd (1945) and Adams (1942). The mechanism of action of Marihuana has been experimentally investigated by Joel (1925). His aim was a limited one, as the investigation was part of a series on the vestibular reactions. Joel reports that in intact cats marihuana produces a catatonic picture with swaying. decrease in metility, and cataleptic perseverance. A similar picture was found by Loewe (1945). In decorticate cats swaying is the only sign, while in decerebrate animals there are none. Wikler and Lloyd (1945) using bipolar occipital leads only, investigated electro-encephalograms taken after patients had smoked two or three marihuana cigarettes. There was no significant change in alpha frequency, and in only some of the patients was there a slight decrease in alpha time. Muscle artefacts obscured any cortical fast frequencies. In cats light mixtures of marihuana smoke and air caused the disappearance of from 6 to $9 \mathrm{c}$ /sec. activity, but more concentrated smoke caused a slowing of cortical activity. The New York report (1944) mentions that electroencephalograms taken by Strauss showed an increase in alpha activity. The only conclusion that can be drawn from this is that the higher physiological functions - those mediated by cortex and thalamus in their normal inter-relationship-are the most easily disturbed by marihuana. Most observers are agreed that it is a drug whose central action far outweighs any peripheral effects (for example, Walton, 1938).

According to the New York report the general metabolic changes produced by marihuana are few, Beringer and others (1932) describe more marked changes which suggest that his subjects were in a rather toxic and dehydrated condition. All the changes described, however, throw no definite light on the effect of the drug on the central nervous system.

From the study here reported one may say that synhexyl acts predominantly on the "higher" functions. It appears to impair the activity of most areas of the cortex, although these functions which are commonly localized in the frontal lobe appear to be most affected. In fact the only symptoms which are in contrast to the familiar "frontal-lobe syndrome " are the increased introversion of interest and the clouding of consciousness. The latter may well be secondary to the disturbances in function of so many different spheres of cerebral activity.

\section{Summary}

The effects of synhexyl, a homologue of one of the active principles of marihuana, have been investigated in a group of patients with predominantly depressive characteristics. The symptoms produced were those of general impairment of cerebral function and mild clouding of consciousness. No evidence that the drug is valuable as a treatment for depression was obtained. The symptoms produced were in contrast to those of benzedrine in the same group of subjects. These findings are discussed in relation to the mechanism of action of the drug.

I am indebted to Professor Aubrey Lew is and the late Dr. Guttmann for much kind help and criticism throughout the course of this investigation and for the use of patients in the Maudsley Hospital. I have also to thank Dr. F. Wrigley, of Roche Products Ltd., for kindly supplying the synhexyl.

\section{REFERFNCES}

Adams, R. (1942). Bull. N. Y. Acad. Med., 18, 705.

Beringer, K., von Baever, W., and Marx, H. (1932). Nervenarzt, $\mathbf{5}, 337$.

Cattell, R. B. (1946). J. Pers, 14, 229, 239.

Douthwaite, A. H. (1947). Brit. med. J., 2, 43.

Eysenck, H. J. (1947). "Dimensions of Personality." Kegan Paul. London.

Joël, E. (1925). Pfug. Arch. ges. Physiol., 209526.

Kant, F. (1930). Arch. Psychiatrie, 91, 694.

Kürz, E., and Kraepelin, E. (1901). Psychologische Arbeiten, 3, 417.

Loewe, S. (1944). In " The Marihuana Problem in the City of New York." New York Mayor's Committee. Jacques Cattell Press.

. (1945). Fed. Proc., 4, 127.

Mann, P. J. G., and Quastel, J. H. (1940). Biochem. J., 34, 414.

Mayer-Gross. W., and Guttmann, E. (1936). J. Menl. Sci., 82, 222.

Morrow, R. (1944). In " The Marihuana Problem in the City of New York."

Stockings, G. T. (1947). Brit. med. J., 1, 918.

Todd, A. R. (1945). Experientia, 2, 55.

Walton, R. P. (1938). "Marihuana, America's New Drug Problem." J. B. Lippincott and Co. Philadelphia.

Wikler, A., and Lloyd, B. J., Jr. (1945). Fed. Proc., 4, 141 . 